\title{
INVOLVEMENT OF OLDER PEOPLE IN EMPLOYMENT IN LATVIA
}

Janis Kudins ${ }^{1}$, Ph.D.

${ }^{1}$ Daugavpils University

\begin{abstract}
Demographic transformation and increase of older people in Europe have encouraged discussions regarding how economics could help older people to grow old in a dignified way and be active in labour market. In Latvia the term older people is usually applied to pensioners. In this research the author analysed the number of pensioners in Latvia from 2012 till 2018, as well as change of pensioners' employment level in population aged 45 and over. This research showed that $63.1 \%$ of pensioners (45 years old and over) in Latvia were employed in 2018. Compared to 2012 the amount of employed pensioners in 2018 has increased by $10.2 \%$. Regression analysis between employed pensioners and average pension in Latvia from 2004 till 2018 shows a statistically significant linear interrelationship $\left(R^{2}=0,723\right)$ but the data correlation analysis shows a strong positive correlation $(r=0,850)$.
\end{abstract}

Key words: older people, pensioners, employment, amount of pensions, Latvia.

JEL code: J14 , J26, I32, I38

\section{Introduction}

The demographic transformations in states around the world, such as increasing number and proportion of older people, indicate a new situation in economics - global ageing and the longevity revolution (Bank of America, 2014). These two notions give objective evidence that all the aspects of society and economics must be based on a new point of view, which is founded on the research of older people needs, employment and quantitative changes in this group.

The importance and urgency are confirmed by the Political Declaration and Madrid International Plan of Action on Ageing (United Nations, 2002), which stresses that governments should in particular think about the standard of living, quality of life and the ability of being active in regards to older people. This plan marks a transition in the 21st century to a society, which would be open for people of all ages, including society, which creates an enabling and supporting environment for older people too.

The urgency of this problem in Latvia is highlighted by the fact that the involvement of older people in employment is also on the political agenda - this is one of the means how to decrease the dependency ratio, which is felt by the society in Latvia (Central Statistical Bureau of Latvia, 2020b; 2020h; 2020a), as well as its negative impact on the economic growth and also address aspects of social security (The Saeima of the Republic of Latvia, 2010).

\section{Research results and discussion}

Research aim: to analyse the economic aspects of involvement of older people in employment in Latvia. Research tasks: 1 ) to research the theoretical thoughts regarding the problematics of older people group's definition; 2) to analyse the employment aspects of older people in Latvia in context with average pension. Research methods: the research employed qualitative methods for theoretical literature review, while numerical data were processed using statistical analysis, regression analysis and correlation analysis. Research sources and materials: information from the Central Statistical Bureau, documents, statistics and researches from Latvia and international organizations were used.

Research limitations. In this research term older people is applied to pensioners, who in 2004-2018 constituted four subgroups in Latvia - old-age pensioners, disability pensioners, service

1 Janis Kudins e-mail: janis.kudins@du.Iv 
pensioners, pensions under special regulations. Number of pensioners in Latvia is determined as the total sum of pensioners in these subgroups. Taking into account that in 2004-2016 old-age pensioners in Latvia were people aged 45 and over (in 2016 there were $0.1 \mathrm{~K}$ old-age pensioners in the age group of 45-54), employment level of pensioners (\%) was calculated for population aged 45 and over.

\section{Theoretical background}

The term older people is ambiguous (Roebuck, 1979) and is frequently linked with the old-age pension's requirement - minimal age, which gives the right to receive this social security (World Health Organization, 2002). Usually in European countries this term is applied to people aged 65 and over but there is also another gradation.

Use of chronological age as a marker for the timing of old-age is not equivalent to biological age; however, in the same time it is universally recognized that these two criteria are not necessarily synonyms. United Nations analyses trends in population ageing by looking at the changes in population aged 60 and over (United Nations, 2015). Nevertheless, there may be other factors, not only chronological age (as it is in the majority of countries around the world) that could be the basis for the research of socio-economic and health aspects (Kowal, 2001). At the end of the 19th century so called Friendly Societies were starting to form in Great Britain (Parliament of the United Kingdom, 1875). The members of these organizations paid in small amounts of money over a long period of time in order to later share between themselves resources and provide economic independence and social security in case of illness and old-age (Shepherds Friendly, 2020). These Friendly Societies defined old age as any age after 50; however, mostly they used age of 60 or 65 as the benchmark for these pension schemes (Roebuck, 1979).

This shows that the term older people is multidimensional - it can be looked at as a chronological age, age related with fulfilling the requirements for old-age pension, psychological age or person's ability to be functionally active in society or other criteria. Term pension age is complex and includes several of these criteria; nonetheless people over the age of 50 have many characteristic features, which allow characterizing them as older people (World Health Organization, 2002). One of these features is the gradual losing of active role in labour market.

United Nations have concluded that involvement of older people in employment is not only the objective reality but also a vital necessity - societies around the world, including Latvian, are growing old. Therefore, different kinds of support should be provided for older people (age 50 and over), including creation of enabling environment for their employment (AAL Market Observatory, 2018). Global ageing is a new and dynamic process - it is anticipated that in year 2050 the population aged 60 and over will have increased by 1.1 B in comparison with year 2013, as well as altogether there will be 2B of older people around the globe (Bank of America, 2014).

The increase of older people has encouraged discussions regarding the role of economics in helping older people to grow old in a dignified way and be active in labour market. The Active and Assisted Living (AAL) approach is aimed to improve social care system and quality of life for older people (AAL Market Observatory, 2018). This approach is being implemented in Europe as of 2008.

In 2030, the number of population aged 60 and over in Latvia will have increased by $2.4 \%$ in comparison with year 2015, in Estonia - by $3.0 \%$, in Lithuania - by $4.7 \%$ (United Nations, 2015). This shows that Baltic region will have similar challenges in the future - providing and improving the quality of life for older people. This task is especially important for Latvia, as the average pension in 
Latvia is lower than the poverty threshold - in 2017 the average paid out pension was 297.6 euro (Central Statistical Bureau of Latvia, 2020f), but the poverty threshold for a single person household was 367 euro. The at-risk-of-poverty rate for a single person (aged 65 and over) household reached 74\% in 2017; for two adults without any dependent children the rate was $24.9 \%$ (Central Statistical Bureau of Latvia, 2019).

Low pensions and insufficient income from other sources (kitchen garden, dividends etc.) are factors which could encourage older people to continue working after retirement or get employed at a later time. For the national economy of Latvia, it would be important to increase the employment level of older people, since the available workforce cannot cover the demand of labour market in the last few years. The urgency of this problem is also backed by the increase of vacancies in Latvia (Central Statistical Bureau of Latvia, 2020c). Therefore, it is important to research factors, which could influence the involvement of older people in employment and help with filling these vacancies.

\section{Research results and discussion}

Author analysed changes in the number of pensioners in Latvia in this research, as well as determined the number of employed pensioners in 2004-2018. It can be derived from this research that in $201845.4 \%$ of the total population aged 45 and over were working pensioners and this proportion has grown by 15.0 percentage points in comparison to 2012 (Table 1). Changes in the number of pensioners in age subgroups were uneven - in 2018 compared to 2012 the number of pensioners aged 45-54 decreased by $12.1 \%$, in age group 55-64 the decrease was even bigger $26.5 \%$, but for age group 65 and over there was an increase of $3.9 \%$. The decrease of pensioners aged 45-54 and 55-64 in 2018 compared to 2012 could be explained with the gradual increase of state pension age - at the beginning of 2014 the state pension age in Latvia was 62 years and three months; at the beginning of 2020 it is already 63 years and nine months and in 2025 it will be 65 (Saeima of the Republic of Latvia, 1995; State Social Insurance Agency, 2018).

Table 1

Number and employment level of pensioners aged 45 and over

\begin{tabular}{|l|l|c|c|c|c|c|c|c|c|}
\hline No & \multicolumn{1}{|c|}{ Indicator } & $\mathbf{2 0 1 2}$ & $\mathbf{2 0 1 3}$ & $\mathbf{2 0 1 4}$ & $\mathbf{2 0 1 5}$ & $\mathbf{2 0 1 6}$ & $\mathbf{2 0 1 7}$ & $\begin{array}{c}\mathbf{2 0 1 8} \\
\begin{array}{c}\text { Change, } \\
\mathbf{2 0 1 8} / \\
\mathbf{2 0 1 2} \%\end{array}\end{array}$ \\
\hline 1. & $\begin{array}{l}\text { Pensioners* aged 45 and } \\
\text { over, in K }\end{array}$ & 549.2 & 544.3 & 541.1 & 537.2 & 533 & 529.7 & 526.1 & -4.2 \\
\hline \multicolumn{7}{|c|}{ Including } \\
\hline 1.1. & $\begin{array}{l}\text { Pensioners aged 45-54, in } \\
\text { K }\end{array}$ & 30.7 & 30.4 & 29.8 & 29.2 & 28.5 & 27.6 & 27.0 & -12.1 \\
\hline 1.2. & Pensioners aged 55-64, K & 131.1 & 123.8 & 116.2 & 110.5 & 104.4 & 100 & 96.4 & -26.5 \\
\hline 1.3. & $\begin{array}{l}\text { Pensioners aged 65 and } \\
\text { over, in K }\end{array}$ & 387.4 & 390.1 & 395.1 & 397.5 & 400.1 & 402.1 & 402.7 & 3.9 \\
\hline 2. & Employed pensioners, in K & 301.1 & 308.2 & 310.8 & 317.6 & 326.0 & 329.6 & 331.8 & 10.2 \\
\hline 3. & $\begin{array}{l}\text { Employment level of } \\
\text { pensioners aged 45 and } \\
\text { over, in \% }\end{array}$ & 39.5 & 40.7 & 41.4 & 42.6 & 44.1 & 44.9 & 45.4 & pp. \\
\hline
\end{tabular}

Source: author's calculations based on Central Statistical Bureau of Latvia, 2020d, 2020e, 2020i, 2020g

In 2018 , there were $331.8 \mathrm{~K}$ employed pensioners $(63.1 \%$ of all pensioners) (Table 1$)$. In comparison with 2012, the number of employed pensioners in 2018 increased by $10.2 \%$ and its proportion in population aged 45 and over was $45.4 \%$. It can be deduced that the employment level of pensioners aged 45 and over has gradually increased in 2012-2018, which means that there are objective factors encouraging labour supply for pensioners. 
The involvement of pensioners in employment can be influenced by several factors, including the amount of pension; therefore, the author decided to research this aspect in particular. By analysing the average pensions in Latvia, it can be concluded that in 2018 the average pension has increased by 71.9 euro (27.9 \%) in comparison with the average pension in 2012 (Central Statistical Bureau of Latvia, 2020h; Table 2).

Table 2

Average pensions in Latvia in 2012-2018

\begin{tabular}{|l|l|l|l|l|l|l|l|l|c|c|}
\hline No & Indicator & $\mathbf{2 0 1 2}$ & $\mathbf{2 0 1 3}$ & $\mathbf{2 0 1 4}$ & $\mathbf{2 0 1 5}$ & $\mathbf{2 0 1 6}$ & $\mathbf{2 0 1 7}$ & $\mathbf{2 0 1 8}$ & $\begin{array}{c}\text { Absolute } \\
\text { change, } \\
\text { euro }\end{array}$ & $\begin{array}{c}\text { Change, } \\
\mathbf{2 0 1 8} / \\
\mathbf{2 0 1 2} \text { \% }\end{array}$ \\
\hline 1. & $\begin{array}{l}\text { Old-age } \\
\text { pension }\end{array}$ & 256.5 & 259.2 & 266.3 & 273.4 & 279.6 & 289.4 & 313.8 & 57.3 & 22.3 \\
\hline 2. & $\begin{array}{l}\text { Disability } \\
\text { pension }\end{array}$ & 166.4 & 163.3 & 164.4 & 164.4 & 163.5 & 164.1 & 168.8 & 2.4 & 1.4 \\
\hline 3. & $\begin{array}{l}\text { Service } \\
\text { pension }\end{array}$ & 287.5 & 295.0 & 303.8 & 314.4 & 328.7 & 346.9 & 383.3 & 95.8 & 33.3 \\
\hline 4. & $\begin{array}{l}\text { Average } \\
\text { pension* }\end{array}$ & 257.9 & 264.2 & 271 & 276.8 & 283.5 & 297.6 & 329.8 & 71.9 & 27.9 \\
\hline
\end{tabular}

Designations: Average pension*, including pensions under special regulations Source: author's calculations based on Central Statistical Bureau of Latvia, 2020h

The most significant change in the amount of pension can be seen in service pension group - the increase is 95.8 euro (33.3\%); whereas disability pension has seen practically no increase - on average it has increased by 2.4 euro (1.4\%) in 2018 (compared to 2012). The average old-age pension in 2018 was 329.8 euro, which means that compared to 2012 it has increased by 71.9 euro (27.9\%).

The analysis of proportion of pensioners according to the amount of pension showed that $194.2 \mathrm{k}$ (38.3\%) from all old-age pension's recipients received a pension lower than 300 euro per month in 2018 (Fig. 1). Furthermore, 10.7 \% of the old-age pension's recipients received less than 100 euro per month; the biggest proportion of old-age pension's recipients - 53.8 \% - received 250-300 euro per month (Central Statistical Bureau of Latvia, 2020h).

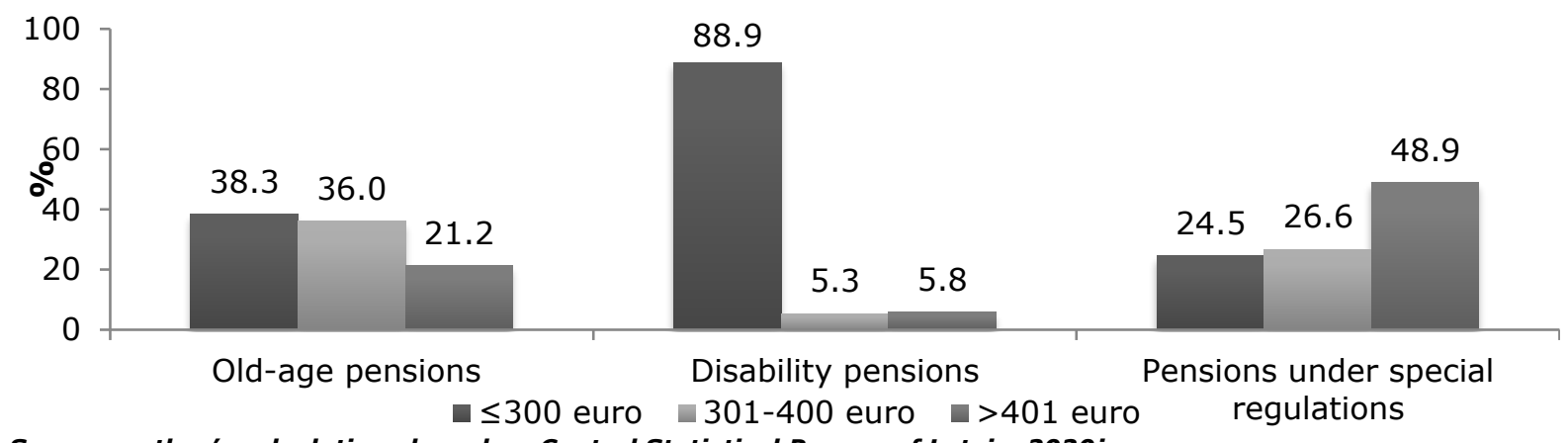

Source: author's calculations based on Central Statistical Bureau of Latvia, 2020j.

Fig. 1. Breakdown of pension recipients in Latvia based on the average pension in pension subgroups in 2018 , in \%

$74.3 \%$ of old-age pensions', $94.2 \%$ of disability pensions' and $51.1 \%$ of pensions' under special regulation recipients received less than 400 euro per month in 2018 (Fig. 1.). Therefore, one can deduce that many single pensioner households were below the poverty threshold, as in 2018 it was set to 409.3 euro for a single person household (CSB, 2020f). This is especially relevant for the recipients of minimum old-age pension, and the Constitutional Court of Latvia has recognized it as a social problem (Paparde, 2020; Gruntmane, 2019).

In labour market, there is a correlation between a person's labour activity or job offer and the minimum income level for the providing of basic needs (Dudin, M., Lyasnikov, N., Klepova, T., Sukhova, E., Sizova, Y., 2018). Low pensions can be one of the factors that influence pensioners' 
decision to be employed. Additionally, labour market has to be ready to supply work places for older people according to the aim of European countries to decrease poverty and social exclusion (European Commission, 2010).

This research shows that in Latvia there is a linear regression $\left(R^{2}=0,723\right)$ (Fig. 2) between the changes in the number of employed pensioners and average pension, and it can be described with this equation (1):

$$
y=0.306 x+224,794
$$

where:

$y$ - number of employed pensioners, $x$ - amount of pension in the specific period, $R$ - determination coefficient.

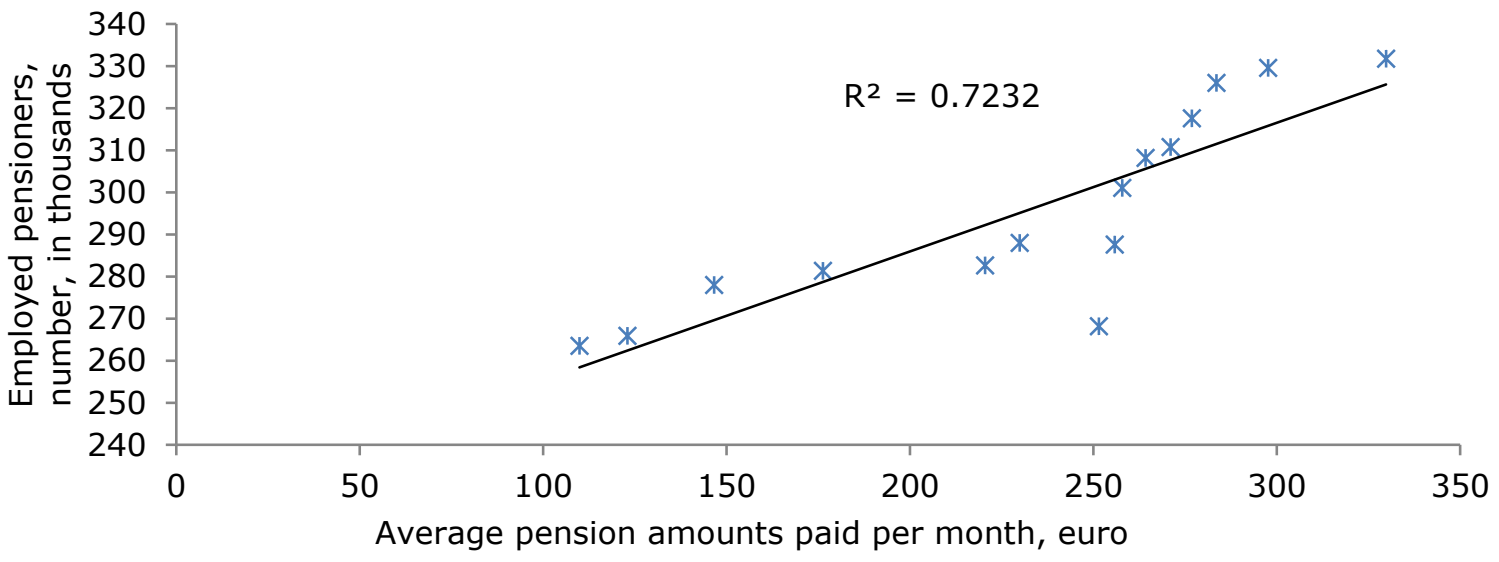

Source: author's calculations based on Central Statistical Bureau of Latvia, 2020j

Fig. 2. Correlation between the number of employed pensioners and amount of pension in 2004-2018 in Latvia

The absolute value of model correlation ratio was $0.850(r=0.850 ; p=0.05 ; 13=0.000<r)$, which demonstrates that there is a strong positive correlation. Since the model $(1) F$ value's $(F=33,962) p$ value is $p=0.00$, the model with the probability of $95 \%$ is statistically significant. Based on this research, it can be concluded that the labour supply for pensioners is statistically influenced by the amount of pensions.

\section{Conclusions, proposals, recommendations}

1) The definition of the age of older people differs between countries, and the term older people can be associated with chronological age, biological age, psychological age, ability to be active in society, set state pension age and other factors. In Europe, this term is usually applied to population aged over 65; however, the United Nations, when analysing problematics of older people, look at the population aged 60 and over. In Latvia, this term is usually applied to pensioners, who can be divided in subgroups based on the type of pension - old-age, disability and pensions under special regulations.

2) Statistical data for 2018 show that in Latvia $74.3 \%$ of old-age pensions', $94.2 \%$ of disability pensions' and $51.1 \%$ of pensions' under special regulation recipients received less than 400 euro per month and, as a result, single pensioner households were counted as poor.

3) The number of employed pensioners (aged 45 and over) is gradually increasing - the increase in 2018 (compared to 2012) was $10.2 \%$. Moreover, the employment level of pensioners aged 45 and over is increasing as well - the increase in 2018 (compared to 2012) was 15 percentage points. 
4) Regression analysis of the statistical data from 2004-2018 showed that there is a linear correlation $\left(R^{2}=0,723\right)$ between the number of employed pensioners and the amount of pension. This proves that the amount of pension is a significant economic factor, which impacts the labour supply of older people in labour market. The impact of other factors on pensioners' decision to be employed, as well as the question, if the total income level of employed pensioners provides for their economic needs, should be analysed in the next studies.

\section{Bibliography}

1. AAL Association (2019). Ageing Well in the Digital World. AAL Programme. Brussels, Belgium. Available: http://www.aal-europe.eu/

2. AAL Market Observatory (2018). The EU Silver Economy: Market Size, Challenges and Opportunities. June 12, 2018. Available: https://www.activeadvice.eu/news/market-insights/the-eu-silver-economy-marketsize-challenges-and-opportunities/

3. Apollo.Iv. (2019). Uznemumos un valsts iestades ir vairak neka 30000 vakantas darbavietas (There are More than 30000 Vacancies in Companies and Public Institutions). Available: https://www.apollo.Iv/6779597/uznemumos-un-valsts-iestades-ir-vairak-neka-30-000-vakantasdarbavietas

4. Bank of America (2014). Silver Dollar - Longevity Revolution Primer. Thematic Investing. Merrill Lynch. Available: https://ec.europa.eu/research/innovation-union/pdf/active-healthy-ageing/merrill.pdf

5. Central Statistical Bureau of Latvia. (2020a). IRG030. Average Age and Number of Population in Statistical Regions and Cities under State Jurisdiction by Age and Gender; at the Beginning of the Year. Available: http://data1.csb.gov.Iv/pxweb/lv/iedz/iedz__iedzrakst/IRG030.px/

6. Central Statistical Bureau of Latvia. (2020b). IRG020. Demographic Burden in Statistical Regions, Cities under State Jurisdiction and Counties; at the Beginning of the Year). Available: http://data.csb.gov.Iv/pxweb/en/iedz/iedz_iedzrakst/IRG020.px/

7. Central Statistical Bureau of Latvia. (2020c). Social Processes. JVSG040. Job Vacancies by Kind of Economic Activity on Average per Year. http://data.csb.gov.Iv/pxweb/en/sociala/sociala_aiznemtdv_ikgad/JVSG040.px/

8. Central Statistical Bureau of Latvia. (2020d). NBG070. Employed by Age Group and Sex. Available: https://data1.csb.gov.Iv/pxweb/en/sociala/sociala_nodarb_nodarb_ikgad/NBG070.px

9. Central Statistical Bureau of Latvia. (2020e). NBG330. Inactive Population by Status and Sex. Available: https://data1.csb.gov.Iv/pxweb/lv/sociala/sociala_nodarb_aktivitate_ikgad/NBG330.px/

10. Central Statistical Bureau of Latvia. (2020f). NIG020. At-Risk-of-Poverty Threshold (Ilustrative Values). Available:

https://data1.csb.gov.Iv/pxweb/en/sociala/sociala_nabadz_nevienl_monetara_nab/NIG020.px/table/table ViewLayout1/

11. Central Statistical Bureau of Latvia. (2019g). NBG021. Employment Rate by Ethnicity and Sex (\%). Available: https://data1.csb.gov.Iv/pxweb/en/sociala/sociala_nodarb_nodarb_ikgad/NBG021.px

12. Central Statistical Bureau of Latvia. (2020h). SDG030. Average Size of Pensions Paid (euro) Available: http://data1.csb.gov.Iv/pxweb/en/sociala/sociala__socdr__pensijas_ikgad/SDG030.px/table/tableViewLayo ut1/

13. Central Statistical Bureau of Latvia. (2019i). SDG020. Number of Pension Recipients by Age and Type of Pension at End of the Year (thsd Population). Available: https://data1.csb.gov.Iv/pxweb/en/sociala/sociala_socdr_pensijas_ikgad/SDG020.px/

14. Central Statistical Bureau of Latvia. (2020j). SDG040. Number of Pension Recipients by Average Size of Pension Granted. Available: https://data1.csb.gov.Iv/pxweb/Iv/sociala/sociala__socdr_pensijas_ikgad/SDG040.px/table/tableViewLay out1/

15. Central Statistical Bureau of Latvia. (2019). People at Risk of Poverty and Social Exclusion in Latvia in 2017, in Latvian. Available: https://www.csb.gov.Iv/lv/statistika/statistikas-temas/socialieprocesi/nabadziba/meklet-tema/390-nabadzibas-risks-un-sociala-atstumtiba-latvija

16. Dudin, M., Lyasnikov, N., Klepova, T., Sukhova, E., Sizova, Y. (2018). Economic and Mathematical Modeling of the LaborMarket in Education. International Journal of Pure and Applied Mathematics. Volume 119 No. 17 2018, 1441-1445 ISSN: 1314-3395. Available: https://acadpubl.eu/hub/2018-119-17/4/435.pdf

17. European Commission (2010). Europe 2020 A Strategy for Smart, Sustainable and Inclusive Growth. Available: 147ec91fe88a

18. European Commission (2018). The Silver Economy. Oxford Economics, Technopolis. Directorate-General for Communications Networks, Content and Technology. Personal Author(s): Farla, K., Simmonds, P., Worthington, H., Varnai, P. ISNB. 978-92-79-76905-4. Available: https://op.europa.eu/en/publicationdetail/-/publication/2dca9276-3ec5-11e8-b5fe-01aa75ed71a1/language-en

19. Gruntmane, T. (2019). Iesprostotie pensionari (Trapped Pensioners). In: Ir. Available: https://ir.Iv/2019/10/14/iesprostotie-pensionari/ 
20. Kowal, P. (2001). Definition of an Older Person. Proposed Working Definition of an Older Person in Africa for the MDS Project. Technical Report. January 2001 with 12,807 Available: https://www.researchgate.net/publication/264534627_Definition_of_an_older_person_Proposed_working_d efinition_of_an_older_person_in_Africa_for_the_MDS_Project

21. LETA (2017). Currently 60\% Latvian Employers Face a Labour Shortage. News Agency LETA, 11 December 2017. Retrieved: http://nra.Iv/latvija/231270-sobrid-ar-darbaspeka-trukumu-saskaras-jau-60-latvijasuznemeju.htm. Access: 21.01.2018.

22. Parliament of the United Kingdom (1875). Friendly Societies Act. Available: https://en.wikipedia.org/wiki/Friendly_Societies_Act.

23. Paparde, I. (2020). Vertes minimalas pensijas atbilstibu Satversmei (Value of the Minimum Pension in Accordance with the Satversme). In: nra.Iv.27.01.2020. Available: https://nra.Iv/latvija/303097-vertesminimalas-pensijas-atbilstibusatversmei.htm?utm_source=inboxlv\&utm_campaign=inboxIvNews\&utm_medium=button

24. Roebuck, J. (1979). When Does "Old Age Begin?": The Evolution of The English Definition. Journal of Social History, Volume 12, Issue 3, Spring 1979, Pages 416-428. Available: https://academic.oup.com/jsh/articleabstract/12/3/416/921395?redirectedFrom=fulltext

25. Saeima of the Republic of Latvia (1995). On State Pensions. Available: http://www.varam.gov.lv/lat/pol/ppd/?doc=13857https://likumi.lv/ta/id/38048-par-valsts-pensijam

26. Saeima of the Republic of Latvia (2010). Latvijas ilgtspējīgas attīstības stratēǵija līdz 2030. gadam. Latvija 2030 (Sustainable Development Strategy of Latvia until 2030). Available: http://www.varam.gov.lv/lat/pol/ppd/?doc=13857

27. Shepherds Friendly (2020). What is a Friendly Society? Available: https://www.shepherdsfriendly.co.uk/yourresource-centre/what-is-a-friendly-socety

28. State Social Insurance Agency (2018). Three Levels of Pension System. Available: https://www.vsaa.gov.Iv/pakalpojumi/pensionariemsenioriem/vecuma-pensija/pensijas-vecumapaaugstinasana-no-62-lidz-65-gadu-vecumam/

29. United Nations (2015). World Population Ageing 2015. Department of Economic and Social Affairs Population Division. New York, $2015 . \quad$ Available: https://www.un.org/en/development/desa/population/publications/pdf/ageing/WPA2015_Report.pdf

30. World Health Organization (WHO), (2002). Proposed Working Definition of an Older Person in Africa for the MDS Project. Health Statistics and Information Systems. Available: https://www.who.int/healthinfo/survey/ageingdefnolder/en/ 